Stigmatisation and self-esteem of persons in recovery from mental illness: the role of peer support.

Mieke Verhaeghe

Piet Bracke

Kevin Bruynooghe 


\begin{abstract}
BACKGROUND: Persons with mental health problems often experience stigmatisation, which can have detrimental consequences for their objective and subjective quality of life. Previous research seeking for elements buffering this negative association focused on coping strategies and revealed that none of the most often used strategies is successful.

AIMS: This article studies whether peer support among clients can moderate this negative link, and to which extent. Following the buffering hypothesis on stress and social support it was expected that the association between stigmatisation and self-esteem would be less among persons experiencing greater peer support.

METHODS: This research problem was studied by means of ordinary least squares regression analysis using quantitative data from structured questionnaires completed by 595 clients of rehabilitation centres.

RESULTS AND CONCLUSIONS: The results confirm that stigmatisation is negatively related to selfesteem, while peer support is positively linked with it. Furthermore, they show that peer support moderates the negative association between stigmatisation and self-esteem, but not in the expected way. These findings suggest that peer support can only have positive outcomes among clients with few stigma experiences, and that stigmatisation itself could impede the formation and beneficial consequences of constructive peer relationships among persons receiving professional mental health care.
\end{abstract}




\section{STIGMATISATION AND SELF-ESTEEM OF PERSONS IN RECOVERY FROM MENTAL ILLNESS: THE ROLE OF PEER SUPPORT.}

\section{INTRODUCTION}

Numerous studies have demonstrated the existence of negative attitudes towards persons with mental health problems (Huxley, 1993 a \& b; Hayward \& Bright, 1997; Crisp et al., 2000; Phelan et al., 2000; Angermeyer \& Matschinger, 2005). According to the original labelling perspective on mental illness (Scheff, 1966) the label 'mentally ill' activates these negative attitudes, resulting in social rejection of clients of mental health services. Furthermore, the modified labelling theory (Link et al., 1987, 1989) describes how people know that the negative attitudes become relevant once they are labelled, which leads to fear of rejection and devaluation. Leaning on these arguments, several authors revealed that there are detrimental consequences of stigmatisation to the self-esteem of labelled persons (e.g. Link et al., 2001; Wright et al., 2000; Hayward et al., 2002). Others, however, disputed this link. One of their counterarguments is that labelled persons could seek coping strategies to deal with stigmatisation (e.g. Miller \& Major, 2000). A study of Link et al. (1991) showed that three of the most often used coping strategies among persons with mental health problems-secrecy, education and avoidance/withdrawal—are not effective. In this study, we examine whether the same is true for another possible buffer: social support. We are especially interested in whether peer support can modify the assumed negative link between stigmatisation and self-esteem. This is of importance for several reasons. First, it contributes to the discussion about the existence of a negative association between both variables, as opinions differ on this topic. Furthermore, it links the literature on the consequences of stigmatisation with the general literature on the social stress process and the role of social support. Despite the fact that some authors argue that stigma should be considered as a stressor (e.g. Miller \& Major, 2000), and the fact that the role of coping strategies is studied (e.g. Link et al., 1991), the role of social support as a buffer has not yet been studied. Finally, this study also has practical implications. As self-esteem could be affected by stigmatisation, it is important to seek for elements impeding this negative relationship.

Self-esteem can be considered as a central component of subjective well-being and mental health in general (Arns \& Linney, 1993; Rosenfield, 1997; Markowitz, 2001), and its enhancement is one of the crucial goals in the rehabilitation of persons with psychological problems (Anthony et al., 
1990). Self-esteem theory (Rosenberg et al., 1989) sees self-esteem as a fundamental human motive: all persons strive for self-maintenance or self-enhancement. According to this approach, self-esteem has three sources: reflected appraisals, self-perceptions and social comparisons (Gecas, 1982, 1989). This means that perceiving that others appreciate and like you, perceiving one's self performing efficacious actions, and comparing one's self favourably with others, enhances self-esteem.

Stigmatisation can affect the self-esteem of persons with mental health problems in a direct and indirect way. Direct rejection can lead to perceptions of being negatively evaluated and these negative appraisals diminish self-esteem. However, more subtle mechanisms can also be at work. Being officially labelled as mentally ill leads to expectations of devaluation and discrimination (Link, 1987) and so-called incidental stigma reminds labelled persons of their devalued status (Link \& Phelan, 1999). As labelled persons perceive that they belong to a devalued social category, they may devalue themselves, even when no direct rejection takes place. Their expectations of being discriminated against or devalued may enhance feelings of shame or a belief that they are set off from others and thus are very different, and may therefore cause them to re-evaluate and re-conceptualize themselves. Three other ways in which stigmatisation could affect self-esteem are unfavourable social or temporal comparisons, the loss of valued roles and relationships, and lowered perceptions of personal control (Camp et al., 2002). Several studies have reported empirical evidence about a negative link between stigmatisation and self-esteem (e.g. Rosenfield, 1997; Link et al., 2001; Wright et al., 2000; Hayward et al., 2002; Verhaeghe, 2003). On the other hand, several other authors argue that stigmatisation and self-esteem are not necessarily related (Crocker, 1999; Camp et al., 2002; Herman and Miall, 1990). Therefore, the first research question of this study is whether stigmatisation and self-esteem are (negatively) linked in the sample under study.

One of the several arguments against the negative link between stigmatisation and selfesteem is the possible attenuating effect of coping strategies (Miller \& Major, 2000; Miller \& Kaiser, 2001). The general reasoning behind this position is that the stress linked with stigmatisation will only be detrimental for well-being if persons are not able to deal with it successfully. The effectiveness of these coping strategies however, is also a subject of discussion (Thoits, 1995; Miller \& Major, 2000; Herman, 1993). Link et al. (1991) conducted empirical research to examine the effectiveness of three coping strategies in the case of stigmatisation of persons with mental health problems, which are prominent in the literature on stigmatisation and are recommended by health professionals to their 
clients: secrecy, education and withdrawal/avoidance. The results of their study revealed that none of these mechanisms moderates the negative consequences of stigmatisation. Another important buffer in the general stress literature-social support-is paid less explicit attention to, when studying the impact of stigmatisation of persons with mental health problems on well-being.

The general literature on stress and social support reveals that persons experiencing more support will suffer less from the negative effects due to stressors (Cohen \& Wills, 1985). Certain types of support are especially important: having people to talk about problems with (appraisal or informational support), and having people who make you feel better about yourself (self-esteem or esteem support). Socioemotional support-defined as assertions or demonstrations of love, caring, esteem, value, empathy, sympathy and/or group-belonging-from significant, or primary, others appears to be the most powerful predictor of reduced psychological distress (Thoits, 1985), because it bolsters one or more aspects of self that have been threatened by objective difficulties. Furthermore, Thoits (1985) states empathetic understanding as a precondition for emotional support to be efficacious. According to her, this is most likely to come from socially similar others facing or having faced the same stressors, as similar others have more detailed knowledge of the situation and are more likely to identify and address the problems perceived by the distressed individual. Furthermore, as shared experience teaches persons that they are not the only ones with difficulties, it reduces selfblame (Rosenfield \& Wensel, 1997). In mental health services other clients or peers can be considered as similar others.

Peer support is considered as an important element in the recovery of persons with mental health problems (Anthony, 1993; Davidson et al., 1999). Concerning its specific role in the stigma process, it is suggested that peer groups can help to 'gain insight, support and ideas for action to address their stigma problems' and to 'consider new, more effective ways of confronting stigma by sharing their experiences, supporting each other, and rehearsing various ways to handle their stigma encounters' (Dudley, 2000: 452), but the empirical evidence about its functioning is scarce. Corrigan (2003), for instance, reveals that stigmatisation can increase in-group feelings, which improve selfesteem, but meanwhile, he acknowledges that few studies exist about the usefulness of this general reasoning for persons with mental health problems. Link et al. (1991) showed that withdrawal to insiders, which constitutes, together with social isolation, one of the three most often mentioned stigma coping strategies, is not efficacious. However, avoidance and withdrawal are taken together in 
that study, and what Goffman (1963) calls the 'own' and 'wise' are not distinguished. Therefore, it remains useful to study the particular effect of 'withdrawal' to the 'own'. Based on this previous research, the second research question concerns the link between peer support and self-esteem: does peer support enhance self-esteem among clients in rehabilitation centres? Furthermore, this study focuses on the specific relationship between stigmatisation, peer support and self-esteem. We are especially interested in whether peer support can moderate the negative link between stigmatisation and self-esteem. This constitutes our third research question.

\section{METHOD AND DATA}

\section{Sample}

The data were collected as part of a larger sociological study of the determinants of well-being of clients and staff members in semi-residential professional mental health organisations in Flanders (Belgium). These services include a large variety of psychotherapeutic, vocational, relaxation and leisure activities and are aimed at day structuring or rehabilitation of persons with more or less sustained psychological problems. The study covers most of the day activity centres connected to the psychosocial rehabilitation centres ( $N=7$ out of 9 centres) and a random sample of day activity centres associated with vocational and social service organisations ( $N=49$ out of 90 organisations). Within each participating agency, the researchers selected a random sample of clients. Size was determined as the daily average number of clients, with a maximum of 30 participants for each centre. Two researchers, who interviewed the clients using structured questionnaires, visited each facility. Due to this approach, retention rates were very high, as we had only a few refusals to participate. In this way, we collected data about 676 clients from 56 centres. However, as not all participants filled in the questionnaires completely, the following analyses are based on data from only 595 clients. This subsample consists of 380 men and 215 women. Their age varies from 16 through 80 , with an average of 44 . Their mean length of stay is nearly 3 years. In Table 1 we provide additional information about these clients and the variables used in the analysis.

\section{Variables}

The dependent variable self-esteem is measured by means of a Dutch translation of Rosenberg's selfesteem scale (Brutsaert, 1993; Bruynooghe et al., 2003). This is a frequently used Likert scale 
containing 10 items with scores from 1 to 5 , which we averaged to obtain a total score, with higher levels expressing more self-esteem (alpha $=.85$ ). The main independent variables are stigmatisation and peer support. A Likert scale that is based on Link et al. (1997) and Fife and Wright (2000) is used to operationalise experienced stigmatisation. This scale (alpha $=.87$ ) consists of five items, such as 'Since I come to the centre, some people treat me with less respect'. The scores from 1 to 5 are averaged to obtain a total score, with higher scores expressing more rejection experiences. In the absence of an internationally standardized and widely used scale measuring peer support among persons with mental health problems in semi-residential settings, we used an instrument that was especially designed for this study. It is a measure of socioemotional support and concerns experiences of appreciation and acceptance by the other clients. It is operationalised by means of a scale consisting of 5 items, such as 'The other clients accept me the way I am', with scores from 1 (fully disagree) to 5 (fully agree), which are averaged to compute a total score (alpha $=.67$ ). Furthermore, an indicator of symptoms is included. Current mental health status is measured by the Brief Symptom Inventory (Derogatis, 1993), using the Dutch translation of the parent instrument (SCL90) by Arrindell \& Ettema (1986). The GSI-score is obtained by computing the mean score on 53 items with scores from 0 to 4 , with higher scores indicating more symptoms (alpha $=.97$ ). We include this measure because some opponents of the labelling theory on mental illness state that stigma experiences are subjective and due to the symptoms, which are manifestations of the mental illness (e.g. Gove, 1970). Their reasoning is that the eventually occurring association between stigmatisation and self-esteem could be explained by a negative, pessimistic, biased perception, typical of persons with mental illness. Furthermore, the argument that lowered self-esteem could be a symptom of the illness itself is also used in the discussion of former research linking stigmatisation with self-esteem (Camp et al., 2002). In response to these critical views, it is necessary to account for psychiatric symptoms. Finally, some background variables are included as controls: gender (men $=1$ ), age (in years), length of stay (in years) and education (primary degree $=1$ to college degree $=4$ ). Table 1 provides a summary of the variables. 


\section{TABLE 1}

\section{Analysis}

Our research problems are analysed by means of ordinary least squares regression analyses, with self-esteem as a dependent variable. In the first step, we included the background variables, followed by our measure of stigmatisation in the second step. Peer support is added to our model in the third step. Finally, to test the buffering hypothesis, we included an interaction term, which is computed as the multiplication of stigmatisation and the social support indicator. To prevent problems of multicollinearity, which can take place due to a strong correlation between the variables and the product terms, the variables stigmatisation and peer support are centered.

\section{RESULTS}

In Table 3, we present the results of our ordinary least squares regression analysis. After we introduced our background variables in the first step, our measure of stigmatisation is introduced. The negative coefficient shows us that stigmatisation is negatively associated with self-esteem $(\beta=.208 ; p$ $=.000)$ : clients who experience more rejection by their environment because of their attendance at the centre are characterized by lower self-esteem, as we could expect from our literature review. Therefore, we can answer our first research question about a possible negative link between stigmatisation and self-esteem affirmatively. An important note is that symptoms are controlled for. This means that this result cannot be explained by the link of symptoms with both stigmatisation $(R=$ $.355 ; p<.01)$ and self-esteem $(R=-.634 ; p<.01$; see Table 2$)$. Therefore, we disagree with the argument of some opponents of the labelling theory on mental illness that stigma experiences are subjective and that the link between stigmatisation and self-esteem can be completely attributed to the psychopathology of the clients.

\section{TABLE 2}

\section{TABLE 3}

In the third step, we introduce our variable concerning peer contact. Table 3 reveals that peer support itself is positively related with self-esteem $(\beta=.168 ; p=.000)$ : clients who feel appreciated and esteemed by their peers in the centre have more positive self-evaluations. This constitutes the answer to our second research question. This finding is consistent with the view that perceived 
support from similar others bolsters the self (Thoits, 1985). In addition, Table 3 shows that the regression coefficient of stigmatisation diminishes slightly when introducing peer contact in the model. Hence, the negative relation between stigmatisation and self-esteem can be partially attributed to the fact that stigma experiences seem to obstruct peer support. Table 2 already revealed that clients who experience more stigmatisation receive less peer support $(R=.362 ; p<.01)$. Thus, negative outside relationships seem to go together with negative inside ones. A possible explanation could be that socially rejected clients feel ashamed about their attendance of the centre and therefore hesitate to come in contact with peers.

Finally, the buffering hypothesis is tested by introducing an interaction term in the analysis as a fourth step. According to this hypothesis, well-being should be higher among highly supported people than among poorly supported ones, but only under conditions of high stress. Under conditions of low stress, no differences should be found (Cohen \& Wills, 1985). Applying this reasoning to our third research problem, we should find higher levels of self-esteem among clients receiving more peer support, but only under circumstances of high stigmatisation. Table 3 reveals that the interaction term is negative and significant $(\beta=-.069 ; p=.016)$, which implies that peer contact does modify the negative link between stigmatisation and self-esteem. To answer whether this result supports the buffering hypothesis, we take a closer look at the direction of the interaction effect. In Figure 1, the mean scores on our self-esteem measure are compared among clients with low and high stigma experiences, receiving high or low peer support (the distinction between 'high' and 'low' is based on the median). This comparison shows us that we can only find differences in self-esteem between highly and lowly supported clients in the case of low stigmatisation, revealing that peer support is only effective among persons with low stigma experiences, not among those experiencing a lot of stigmatisation. Translated to the general stress literature, this means that our results show that wellbeing only differs between lowly and highly supported persons in the case of low stress. Therefore, we can conclude that our data do not support the hypothesis that peer contact impedes the negative impact of stigmatisation on self-esteem. This result will be discussed in the next section.

FIGURE 1

\section{DISCUSSION AND CONCLUSION}


Persons with mental health problems are often socially rejected, which can have detrimental consequences for their well-being in general and their self-esteem in particular. Can this negative effect of stigma experiences be attenuated? As Link et al. (1991) argued, the issue of coping effectiveness is a matter of no small consequence. If coping works, persons with mental health problems can be trained to use effective coping strategies. The same can be said of the effectiveness of peer support. As self-esteem forms a central component of well-being, and as its enhancement can be regarded as a central goal of rehabilitation, we became very interested in examining whether peer contact can moderate the negative link between stigmatisation and self-esteem. Using data of 595 clients from 56 rehabilitation centres, we studied the relationship between stigmatisation, peer support and self-esteem.

Before turning to the discussion of the central variables, we point out some findings concerning background variables. First, the results revealed that men are higher in self-esteem than women, a finding which is consistent in the literature on gender differences in the self-concept (Kling et al., 1999). Furthermore, a strong, negative link between symptoms and self-esteem is found, which is also revealed in other studies (e.g. Rosenberg, 1989). When symptoms lead persons to perform worse than before, they can come to see themselves as less competent and attribute this to personal failure or inadequacy which leads to lower self-esteem (Rosenberg, 1989). In addition, clients who stay longer in the center are characterized by more self-esteem, which cannot be attributed to peer relationships or symptoms, as these variables are controlled for. Also, this result has been found in other studies (e.g. Commerford \& Reznikoff, 1996). As our results replicate previous findings, they add to the validity of our study.

Before discussing our main results, some shortcomings of our research should also be noted. First, we do not dispose of longitudinal data, which means that we cannot make definite conclusions about the direction of causality in our analyses. From a theoretical viewpoint, we based our analysis on self-esteem theory, which argues that the maintenance and enhancement of self-esteem is a central human motive, and which indicates several sources of self-esteem (Rosenberg et al., 1989). Following this idea, we argued that experiences of stigma could have negative implications for one's self-esteem in both a direct and an indirect way. However, self-esteem could also have an impact on stigma experiences. It is possible that persons who feel worthless stimulate others to avoid them or reject them. Other studies using a longitudinal design showed that the link between stigmatisation and 
self-esteem is bidirectional, but that the impact of stigmatisation on self-esteem is larger than the reverse (e.g. Link, 2001). Following these studies and the theoretical reasoning, we considered selfesteem as the dependent variable, although we cannot make definite conclusions about the direction of the association. A second shortcoming concerns the limitations of our sample. As most of the persons in our study already have a long history concerning psychiatric help, we cannot investigate the differences between 'new' and 'old' clients in the way Link (1987) did.

Despite these shortcomings, we believe that our results do contribute to the discussion about the role of social support in the link between stigmatisation and self-esteem. First, they revealed that persons who feel socially rejected have lower self-esteem. It is very important to notice that this link is found even after controlling for symptoms. Therefore, we disagree with some opponents of the labelling perspective on mental illness, who state that stigma experiences are subjective and attributable to the symptoms itself rather than to reactions by outsiders (Gove, 1970). This finding also refutes the critical view of Camp et al. (2002) who comment on studies examining the relationship between stigmatisation and self-esteem without controlling for symptoms. Moreover, it confirms other studies revealing that clients experiencing more rejection have lower self-esteem (e.g. Link et al., 1991; Wright et al., 2000; Link, 2001; Hayward et al., 2002; Verhaeghe, 2003).

Second, our results showed that peer contact is positively linked with clients' self-esteem. This is consistent with the view that perceived support from similar others bolsters the self (Thoits, 1985), which has also been revealed by other studies of persons with psychological problems (e.g. Bracke, 2002). Therefore, we can confirm that peer contact plays an important role in the maintenance or the recovery of positive self-evaluations for persons with mental health problems. While rejection by 'outsiders' diminishes their self-esteem, support by 'insiders' enhances it.

At the same time, our study showed that peer support could not attenuate the negative link between stigmatisation and self-esteem. A possible explanation could be that stigmatisation impedes the positive effect of social integration among peers. The shame of receiving professional help for psychological problems is possibly so strong that it obstructs group formation, as joining a group with (other) persons with mental health problems could imply identification with these persons, and consequently self-labelling as mentally ill. As stigmatisation can lead to denial of mental health problems (e.g. Spaniol \& Gagne, 1997) as a self-protecting strategy (e.g. Miller \& Kaiser, 2001), persons with mental health problems could hesitate to affiliate with peers as a strategy to deny the 
similarity because they try to protect their self-esteem. The strong negative link between stigmatisation and peer support could be interpreted as a confirmation of this thesis. The fact that persons with more rejection experiences have less peer support could be due to their hesitation in building peer relationships as a denial strategy. Their higher level of stigma experiences could enhance their feelings of shame and, consequently, augment their attempts to distinguish themselves from others with mental health problems. This is in accordance with Goffman's (1963) statement that rejected persons are often ambivalent about others who are similarly marked and attempt to distinguish themselves from these others. Swanson and Spitzer (1970: 49) state that during the admission of hospital patients 'individuals are believed to be most conscious of their spoiled identity and to deny membership, association, or identification with the disparaged group'. Despite the fact that many of the clients in this study have an inpatient history and have had a long length of stay in the current centre, the data suggest that stigmatisation could also affect group identification in these clients.

Our finding concerning a negative link between stigmatisation and peer support is contrary to the results of Link et al. (1989), who argued that positive relationships with persons who know about and accept the stigmatized condition substitute the negative ones with non-household non-relatives. Thus, it is possible that the explanation of Link et al. (1989) is only valid for persons who know and accept the stigmatized condition and who are not peers. Therefore, it remains interesting to distinguish what Goffman (1963) calls the 'own' (persons who are also stigmatized) and the 'wise' (persons who know about the condition and accept it). Furthermore, our result forms an addition to other studies that show how stigmatisation has detrimental effects on the social relationships of persons with mental health problems (e.g. Link et al., 1989; Prince \& Prince, 2002). Besides impairing relationships with persons outside mental health services, it also seems to affect the contacts within.

The lack of support for the buffering hypothesis is surprising in the light of previous research that shows or suggests the importance of peer support in dealing with stigmatisation (e.g. Segal et al., 1993; Dudley, 2000). Many of these studies, however, focused on services where peers are explicitly and purposefully involved in the service delivery (e.g. Salzer \& Shear, 2002; Solomon, 2004; Wilson et al., 1999). In the organisations in our study, this was not the case. To the contrary, staff members of several centres remarked that clients are discouraged from discussing their emotional problems among each other to avoid problems concerning the cost of caring. Therefore, we suggest the possibility that the extent to which clients form a group they identify with and which works as a buffer, 
depends on the service modalities. For that reason, it would be interesting to study these differences between services to reveal the conditions that stimulate a positive effect of peer contact.

Following the discussion of these results, we can formulate several hypotheses for future research. First, we hypothesize that for clients of mainstream professional mental help facilities (i.e., where peer support is not a goal in se), stigmatisation affects self-esteem negatively, whereas peer support enhances it. Second, we hypothesize that in these facilities stigmatisation implies feelings of shame, which impede the formation of peer groups and thus the receipt of peer support. Therefore, we assume an indirect relationship between stigma and self-esteem other than those mentioned in the introduction can be found by the peer support diminishing features of stigmatisation. Third, we hypothesize that peer support does not function as a buffer in mainstream organisations. However, it is possible that it does in specialized peer support facilities, as revealed by other studies. In these organisations clients might also feel less ashamed to form peer groups. Therefore, we hypothesize that in specially designed peer support mental health facilities the link between stigmatisation could diminish because of the self-esteem enhancing features of peer support. Furthermore, in such organizations, stigmatisation could even lead to strong in-group feelings and group identification, which can enhance self-esteem, as suggested by Herman and Miall (1990). The differences among the organizations under study could possibly partially explain the inconsistent findings in the literature. As the link between stigma, peer support and self-esteem seems to depend on the context in general, and on organizational features in particular, we suggest incorporating these in future research.

Before concluding, we wish to remark that not only peer support, but also contact with outsiders is important. Even if peer support reduced the impact of stigmatisation in certain services such as self-help organisations, one should keep in mind that stigmatisation itself can remain as long as insiders remain separated from outsiders. It is outsiders' contact that should be enhanced to destigmatize, as it is one of the most effective means (Couture \& Penn, 2003). Therefore, it remains interesting to distinguish between reducing the impact of stigmatisation and reducing the rejection itself. Both strategies are not always compatible in the short and the long term. For instance, even if coping strategies such as secrecy or avoidance were effective in the short run, and on the individual level—although this is contrary to Link et al.'s (1991) results—-they can contribute to the maintenance of stigmatisation by maintaining the categorisation, classification and separation of persons with mental health problems. The same holds for social support. Even if inside support did reduce the 
impact of stigmatisation in certain services, this does not imply destigmatisation. As Link et al. (1991) argued, withdrawal could have negative effects because it can result in further isolation and because it reinforces the negative self-concept. Therefore, additional research should distinguish the possible effects of the enhancement of inside and outside social relationships on the reduction of stigmatisation and its impact.

To conclude, despite the lack of a buffering effect in this study, the results suggest that peer support should be stimulated. Even if it cannot function as a buffer-at least in those settings where it is not explicitly implemented-it nevertheless seems to enhance self-esteem, which is still one of the key goals of psychiatric rehabilitation. 


\section{REFERENCES}

ANGERMEYER, M.C. \& MATSCHINGER, H. (2005) The stigma of mental illness in Germany: A trend analysis. International Journal of Social Psychiatry, 51(3), 276-284.

ANTHONY, W.A. (1993) Recovery from mental illness: the guiding vision of the mental health service system in the 1990s. Psychosocial Rehabilitation Journal, 16, 11-23.

ANTHONY, W.A., COHEN, M. \& FARKAS, M. (1990) Psychiatric Rehabilitation. Boston, MA: Boston University Press.

ARNS, P.G. \& LINNEY, J.A. (1993) Work, self, and life satisfaction for persons with severe and persistent mental disorders. Psychiatric Rehabilitation Journal, 17, 63-79.

ARRINDELL, W.A. \& ETTEMA, J.H.M. (1986) SCL-90. Handleiding bij een multidimensionele psychopathologie-indicator. Lisse: Swets \& Zeitlinger.

BRACKE, P. (2002) De steun van lotgenoten en therapeuten tijdens psychosociale rehabilitatie. Mens \& Maatschappij, 77, 43-64.

BRUTSAERT, H. (1993) School, gezin en welbevinden. Zesdeklassers en hun sociale omgeving. Leuven: Garant.

BRUYNOOGHE, K., BRACKE, P. \& VERHAEGHE, M. (2003) De psychometrische eigenschappen van een Nederlandstalige versie van de Rosenberg-zelfwaarderingsschaal. Diagnostiekwijzer, 6, 136-145.

CAMP, D.L., FINLAY, W.M.L. \& LYONS, E. (2002) Is low self-esteem an inevitable consequence of stigma? An example from women with chronic mental health problems. Social Science \& Medicine, 55, 823-834.

COHEN, S. \& WILLS, T.A. (1985) Stress, social support, and the buffering hypothesis. Psychological Bulletin, 98, 310-357.

COMMERFORD, M.C. \& REZNIKOFF, M. (1996) Relationship of religion and perceived social support to self-esteem and depression in nursing home residents. Journal of Psychology, 130, 35-50.

CORRIGAN, P.W. (2003) Stigma and disclosure: implications for coming out of the closet. Journal of Mental Health, 12, 235-248.

COUTURE, S.M. \& PENN, D.L. (2003) Interpersonal contact and the stigma of mental illness: a review of the literature. Journal of Mental Health, 12, 291-305. 
CRISP, A.H., GELDER, M.G., RIX, S., MELTZER, H.I. \& ROWLANDS, O.J. (2000) Stigmatisation of people with mental illnesses. British Journal of Psychiatry, 177, 4-7.

CROCKER, J. (1999) Social stigma and self-esteem: Situational construction of self-worth. Journal of Experimental Social Psychology, 35, 89-107.

DAVIDSON, L., CHINMAN, M., KLOOS, B., WEINGARTEN, R., STAYNER, D. \& KRAEMER TEBES, J. (1999) Peer support among individuals with severe mental illness: a review of the evidence. Clinical Psychology: Science and Practice, 6, 165-187.

DEROGATIS, L.R. (1993) Brief Symptom Inventory. Administration, scoring and procedures manual, Minneapolis: NCS Pearson Inc.

DUDLEY, J.R. (2000) Confronting stigma within the services system. Social Work, 45, 449-455.

FIFE, B. \& WRIGHT, E.R. (2000) The Dimensionality of Stigma: A comparison of its impact on the self of persons with HIVIAIDS and cancer. Journal of Health and Social Behavior 41, 50-67.

GECAS, V. (1982) The self-concept. Annual Review of Sociology, 8, 1-33.

GECAS, V. (1989) The social psychology of self-efficacy. Annual Review of Sociology, 15, 291-316.

GOFFMAN, E. (1963) Stigma. Notes on the management of spoiled identity. New York: Simon and Schuster.

GOVE, W.R. (1970) Societal reaction as an explanation of mental illness: an evaluation. American Sociological Review, 35, 873-884.

HANNIGAN, B. (1999) Mental health care in the community: an analysis of contemporary public attitudes towards, and public representations of, mental illness. Journal of Mental Health, $\mathbf{8}$, $431-440$.

HAYWARD, P. \& BRIGHT, J.A. (1997) Stigma and mental illness: a review and critique. Journal of Mental Health, 6, 345-354.

HAYWARD, P., WONG, G., BRIGHT, J.A. \& LAM, D. (2002) Stigma and self-esteem in manic depression: an exploratory study. Journal of Affective Disorders, 69, 61-67.

HERMAN, N.J. (1993) Return to Sender-Reintegrative Stigma-Management Strategies of ExPsychiatric Patients. Journal of Contemporary Ethnography, 22, 295-330.

HERMAN, N.J., MIALL, C.E. (1990) The Positive Consequences of Stigma: Two Case Studies in Mental and Physical Disability. Qualitative Sociology, 13, 251-269. 
HUXLEY, P. (1993a) Location and stigma: A survey of community attitudes to mental illness: 1. Enlightenment and stigma. Journal of Mental Health, 2, 73-80.

HUXLEY, P. (1993b) Location and stigma: a survey of community attitudes to mental illness: 2. Community mental health facilities_anonymity or invisibility. Journal of Mental Health 2, 157164.

KLING, K.C., HYDE, J.S., SHOWERS, C.J. \& BUSWELL, B.N. (1999) Gender differences in selfesteem: a meta-analysis. Psychological Bulletin, 125, 470-500.

LINK, B.G. (1987) Understanding labeling effects in the area of mental disorders: an assessment of the effects of expectations of rejection. American Sociological Review, 52, 96-112.

LINK, B.G., CULLEN, F.T., FRANK, J. \& WOZNIAK, J.F. (1987) The social rejection of former mental patients: understanding why labels matter. American Journal of Sociology, 92, 1461-1500.

LINK, B.G., CULLEN, F.T., STRUENING, E., SHROUT, P.E. \& DOHRENWEND, B.P. (1989) A modified labeling theory approach to mental disorders: an empirical assessment. American Sociological Review, 54, 400-423.

LINK, B.G., MIROTZNIK, J. \& CULLEN, F.T. (1991) The Effectiveness of Stigma Coping Orientations-Can Negative Consequences of Mental-IIIness Labeling be Avoided. Journal of Health and Social Behavior, 32, 302-320.

LINK, B.G., STRUENING, E.L., NEESE-TODD, S., ASMUSSEN, S. \& PHELAN, J.C. (2001) The consequences of stigma for the self-esteem of people with mental illnesses. Psychiatric Services, 52, 1621-1626.

LINK, B.G. \& PHELAN, J.C. (1999) Labeling and stigma. In Handbook of the sociology of mental health. (eds. C.S. Aneshensel \& J.C. Phelan) New York: Kluwer Academic/Plenum Publishers, $481-494$.

LINK, B.G. \& PHELAN, J.C. (2001) Conceptualizing stigma, Annual Review of Sociology, 27, 363385.

MARKOWITZ, F.E. (2001) Modeling processes in recovery from mental illness: Relationships between symptoms, life satisfaction, and self-concept. Journal of Health and Social Behavior, 42, 6479.

MILLER, C.T. \& KAISER, C.R. (2001) A theoretical perspective on coping with stigma. Journal of Social Issues, 57, 73-92. 
MILLER, C.T. \& MAJOR, B. (2000) Coping with stigma and prejudice. In The social psychology of stigma. (eds. T.F. Heatherton, R.E. Kleck, M.R. Hebl \& J.G. Hull) New York: The Guilford Press, 243-272.

PHELAN, J.C., LINK, B.G., STUEVE, A. \& PESCOSOLIDO, B.A. (2000) Public conceptions of mental illness in 1950 and 1960: what is mental illness and is it to be feared? Journal of Health and Social Behavior, 41, 188-207.

PRINCE, P.N. \& PRINCE, C.R. (2002) Perceived stigma and community integration among clients of assertive community treatment. Psychiatric Rehabilitation Journal, 25, 323-331.

ROSENBERG, M., SCHOOLER, C. \& SCHOENBACH, C. (1989) Self-esteem and adolescent problems—modeling reciprocal effects. American Sociological Review, 54, 1004-1018.

ROSENFIELD, S. (1997) Labelling mental illness: the effects of received services and perceived stigma on life satisfaction. American Sociological Review, 62, 660-672.

ROSENFIELD, S. \& WENZEL, S. (1997) Social networks and chronic mental illness: a test of four perspectives. Social Problems, 44, 200-216.

SALZER, M.S. \& SHEAR, S.L. (2002) Identifying consumer-provider benefits in evaluations of consumer-delivered services. Psychiatric Rehabilitation Journal, 25, 281-288.

SCHEFF, T. (1966; 1999) Being mentally ill. A sociological theory. 3rd ed. New York: Aldine De Gruyter.

SEGAL, S.P., SILVERMAN, C. \& TEMKIN, T. (1993) Empowerment and self-help agency practice for people with mental disabilities. Social Work, 38, 705-712.

SIREY, J.A., BRUCE, M.L., ALEXOPOULOS, G.S., PERLICK, D.A., RAUE, P., FRIEDMAN, S.J. \& MEYERS, B.S. (2001) Perceived stigma as a predictor of treatment discontinuation in young and older outpatients with depression. American Journal of Psychiatry, 158, 479-481.

SPANIOL, L. \& GAGNE, C. (1997) Acceptance: Some reflections. Psychiatric Rehabilitation Journal 20, 75-77.

SOLOMON, P. (2004) Peer support/peer provided services. Underlying processes, benefits, and critical ingredients. Psychiatric Rehabilitation Journal, 27, 392-401.

SWANSON, R.M. \& SPITZER, S.P. (1970) Stigma and the Psychiatric Patient Career. Journal of Health and Social Behavior, 11, 44-51. 
THOITS, P.A. (1985) Social support and psychological well-being: theoretical possibilities. In Social support: theory, research and applications. (eds. I.G. Sarason \& B.R. Sarason), pp. 51-72. Dordrecht: Martinus Nijhof.

THOITS, P.A. (1995) Stress, coping, and social support processes-where are we-what next? Journal of Health and Social Behavior, Special Issue, 53-79.

VERHAEGHE, M. (2003) Stigmatisering en levenskwaliteit van personen met psychische problemen in professionele hulpverlening. Mens \& Maatschappij, 78(1), 29-44.

WILSON, M.E., FLANAGAN, S. \& RYNDERS, C. (1999) The friends program: a peer support group model for individuals with a psychiatric disability. Psychiatric Rehabilitation Journal, 22, 239247.

WRIGHT, E.R., GRONFEIN, W.P. \& OWENS, R.J. (2000) Deinstitutionalization, social rejection and the self-esteem of former mental patients. Journal of Health and Social Behavior, 41, 68-90. 
TABLES AND FIGURES

Table 1-Descriptive sample characteristics

\begin{tabular}{lcccc}
\hline $\mathrm{N}=595$ & Mean & Standard Deviation & Minimum & Maximum \\
& & & & \\
\hline Gender (men = 1) & .64 & .48 & .00 & 1.00 \\
Age & 44.21 & 12.73 & 16.00 & 80.00 \\
Education & 2.28 & .97 & 1.00 & 4.00 \\
Length of stay & 2.97 & 3.52 & .00 & 26.00 \\
Symptoms & 1.04 & .82 & .00 & 3.55 \\
Stigmatisation & 2.57 & 1.19 & 1.00 & 5.00 \\
Peer support & 3.80 & .67 & 1.80 & 5.00 \\
Self-esteem & 3.39 & .79 & 1.30 & 5.00 \\
\hline
\end{tabular}

Table 2-Correlations between variables: Pearson's correlation coefficients

\begin{tabular}{|c|c|c|c|c|c|c|c|}
\hline$N=595$ & Age & Education & Length of stay & Symptoms & Stigmatisation & Peer support & Self-esteem \\
\hline $\begin{array}{l}\text { Gender (men } \\
\text { 1) }\end{array}$ & .040 & -.063 & $.099^{*}$ & $-.277^{\star *}$ & $-.081^{*}$ & .047 & $.275^{\star \star}$ \\
\hline Age & & $-.148^{* *}$ & $.335^{\star *}$ & $-.137^{* *}$ & -.057 & $.081^{*}$ & $.141^{* *}$ \\
\hline Education & & & -.015 & .060 & .078 & -.023 & -.037 \\
\hline Length of stay & & & & $-.161^{* *}$ & -.050 & .047 & $.189^{\star \star}$ \\
\hline Symptoms & & & & & $.355^{\star *}$ & $-.199^{* *}$ & $-.634^{* *}$ \\
\hline Stigmatisation & & & & & & $-.362^{\star *}$ & $-.403^{\star *}$ \\
\hline Peer support & & & & & & & $.333^{\star \star}$ \\
\hline Self-esteem & & & & & & & - \\
\hline
\end{tabular}




\begin{tabular}{|c|c|c|c|c|c|c|c|c|c|c|c|c|c|c|c|c|}
\hline & $\begin{array}{l}\text { Unsta } \\
\text { ndard } \\
\text { ised } \\
\text { regre } \\
\text { ssion } \\
\text { coeffi } \\
\text { cient } \\
\end{array}$ & $\begin{array}{l}\text { Stan } \\
\text { dard } \\
\text { Error }\end{array}$ & $\begin{array}{l}\text { Stand } \\
\text { ardis } \\
\text { ed } \\
\text { regre } \\
\text { ssion } \\
\text { coeffi } \\
\text { cient }\end{array}$ & $p$-value & $\begin{array}{l}\text { Unsta } \\
\text { ndard } \\
\text { ised } \\
\text { regre } \\
\text { ssion } \\
\text { coeffi } \\
\text { cient } \\
\end{array}$ & $\begin{array}{l}\text { Stan } \\
\text { dard } \\
\text { Error }\end{array}$ & $\begin{array}{l}\text { Stand } \\
\text { ardis } \\
\text { ed } \\
\text { regre } \\
\text { ssion } \\
\text { coeffi } \\
\text { cient } \\
\end{array}$ & $p$-value & $\begin{array}{l}\text { Unsta } \\
\text { ndard } \\
\text { ised } \\
\text { regre } \\
\text { ssion } \\
\text { coeffi } \\
\text { cient } \\
\end{array}$ & $\begin{array}{l}\text { Stan } \\
\text { dard } \\
\text { Error }\end{array}$ & $\begin{array}{l}\text { Stand } \\
\text { ardis } \\
\text { ed } \\
\text { regre } \\
\text { ssion } \\
\text { coeffi } \\
\text { cient } \\
\end{array}$ & $p$-value & $\begin{array}{l}\text { Unsta } \\
\text { ndard } \\
\text { ised } \\
\text { regre } \\
\text { ssion } \\
\text { coeffi } \\
\text { cient } \\
\end{array}$ & $\begin{array}{l}\text { Stan } \\
\text { dard } \\
\text { Error }\end{array}$ & $\begin{array}{l}\text { Stand } \\
\text { ardis } \\
\text { ed } \\
\text { regre } \\
\text { ssion } \\
\text { coeffi } \\
\text { cient }\end{array}$ & $\begin{array}{l}p- \\
\text { valu } \\
\mathrm{e}\end{array}$ \\
\hline Constant & 3.715 & .131 & & .000 & 3.613 & .128 & & .000 & 3.630 & .125 & & .000 & 3.611 & .125 & & .000 \\
\hline Gender (men $=1$ ) & .172 & .054 & .104 & .002 & .179 & .052 & .109 & .001 & .180 & .051 & .109 & .000 & .181 & .051 & .110 & .000 \\
\hline Age & .002 & .002 & .034 & .317 & .002 & .002 & .033 & .310 & .002 & .002 & .024 & .450 & .001 & .002 & .020 & .541 \\
\hline Education & .009 & .026 & .011 & .726 & .019 & .025 & .023 & .455 & .017 & .025 & .020 & .498 & .019 & .025 & .023 & .435 \\
\hline Length of stay & .016 & .008 & .073 & .031 & .017 & .007 & .074 & .023 & .017 & .007 & .074 & .020 & .018 & .007 & .080 & .013 \\
\hline Symptoms & -.571 & .032 & -.589 & .000 & -.499 & .033 & -.514 & .000 & -.487 & .032 & -.502 & .000 & -.485 & .032 & -.500 & .000 \\
\hline Stigmatisation & & & & & -.138 & .022 & -.208 & .000 & -.101 & .022 & -.152 & .000 & -.099 & .022 & -.149 & .000 \\
\hline Peer support & & & & & & & & & .198 & .038 & .168 & .000 & .200 & .038 & .169 & .000 \\
\hline $\begin{array}{l}\text { Stigmatisation } \mathrm{x} \\
\text { peer support }\end{array}$ & & & & & & & & & & & & & -.069 & .029 & -.072 & .016 \\
\hline $\mathrm{R}^{2}$ & .420 & & & & .458 & & & & .476 & & & & .480 & & & \\
\hline sig $R^{2}$ change & .000 & & & & .000 & & & & .000 & & & & .016 & & & \\
\hline
\end{tabular}


Figure 1 - The link between peer support and self-esteem among clients with low and high stigma experiences

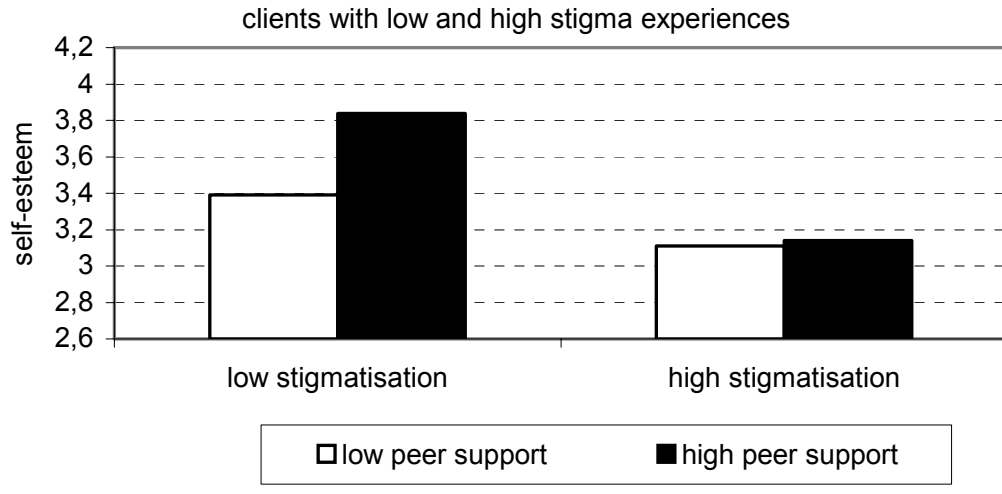




\section{Author information:}

Mieke Verhaeghe

Research Assistant

Department of Sociology

Ghent University

Korte Meer 5

9000 Gent

Belgium

Tel: ++32/(0)9/264 6797

Fax: ++32/(0)9/264 6975

E-mail: Mieke.Verhaeghe@Ugent.be

Piet Bracke

Professor

Department of Sociology

Ghent University

Korte Meer 5

9000 Gent

Belgium

Tel: ++32/(0)9/264 6803

Fax: ++32/(0)9/264 6975

E-mail: Piet.Bracke@Ugent.be

Kevin Bruynooghe

Research Assistant

Department of Sociology

Ghent University

Korte Meer 5

9000 Gent

Belgium

Tel: ++32/(0)9/264 8456

Fax: ++32/(0)9/264 6975

E-mail: Kevin.Bruynooghe@Ugent.be

\section{Foot note:}

A previous version of this paper was presented by the main author at the "Marktdag Sociologie 2005" in Brussels on June 2, 2005. 